\title{
Gottfried Kirch (1639-I7 I0), życie i działalność pierwszego astronoma Królewskiego Pruskiego Towarzystwa Nauk
}

\section{Gottfried Kirch (|639-|7|0) - Life and Work of the First Astronomer of the Royal Prussian Society of Sciences}

Gottfried Kirch (1639-1710) was an astronomer born in Guben, the maker of calendars and the author of ephemerides. He owed his fame to the discovery of the Great Comet of 1680, and he gained prestige as the first astronomer of the Royal Prussian Society of Sciences. The article summarises the current state of knowledge about Gottfried Kirch and presents his astronomical and calednariographic activity at various stages of his life, via the lens of the stays in Langgrün, Lobbenstein, Leipzig, Coburg, Guben and Berlin (Dorotheenstadt).

Keywords: Gottfried Kirch, Royal Prussian Society of Sciences, astronomy, calendars

Słowa kluczowe: Gottfried Kirch, Królewskie Pruskie Towarzystwo Nauk, astronomia, kalendarze

Na kartach historii astronomii zapisał się Gottfried Kirch przede wszystkim jako odkrywca Wielkiej Komety z 1680 r. W swoim dorobku miał również inne osiągnięcia: zaobserwowanie dwóch gwiazd mgławicowych (gromada otwarta M11, gromada kulista M5) i gwiazdy zmiennej $\chi$ Cygni oraz wynalazek mikrometru śrubowego. Popularności przysporzyły mu kalendarze oraz wydawane co roku efemerydy. W swojej karierze przebył długą drogę. Pierwsze kroki w astronomii stawiał bez instrumentów, obserwując gołym okiem i odmierzając czas zegarem piaskowym. Zwieńczeniem jego działalności była pozycja pierwszego astronoma Królewskiego Pruskiego Towarzystwa Nauk, którą sprawował w ostatniej dekadzie swojego życia. Celem artykułu jest prezentacja losów Gottfrieda Kircha i faktograficzne uporządkowanie w tym kontekście jego aktywności astronomicznej i kalendariograficznej'.

1 Trzecim, mniej znanym aspektem działalności Gottfrieda Kircha były obserwacje meteorologiczne. Od ok. 1677 r. prowadził regularne zapisy stanu pogody. Pomiary temperatury, których zbieranie zainicjował w czasie drugiego pobytu w Gubinie, na stałe weszły do repertuaru jego badań po $1700 \mathrm{r}$. 
W historiografii zagranicznej brakuje pozycji, która w ujęciu chronologicznym traktowałaby o dziejach i działalności Kircha. Dotychczasowe publikacje poświęcone astronomowi tylko wybiórczo naświetlają wybrane wątki z jego życia. Największe zasługi w badaniach nad tą postacią położył Klaus-Dieter Herbst, autor edycji korespondencji Kircha, a także spisów jego publikacji i kalendarzy. Niniejszy artykuł reasumuje dotychczasowy stan badań poświęconych astronomowi i uzupełnia go nowymi ustaleniami.

Gottfried Kirch urodził się 8/18 grudnia 1639 r. w Gubinie na Dolnych Łużycach. Przyszedł na świat w domu krawca Michaela Kircha i jego żony, Marii. O najmłodszych latach życia astronoma zachowało się niewiele wiadomości. Garść informacji zawiera pierwszy życiorys uczonego, załączony do wydanej tuż po jego śmierci mowy pogrzebowej autorstwa Johanna Gustava Reinbecka (1683-1741). Na skutek perturbacji wywołanych przez wojnę trzydziestoletnią (1618-1648) rodzina Kirchów musiała zbiec do Polski. Rodzice Gottfrieda stracili wtedy majątek i popadli w biedę. Po powrocie do Gubina zadbali jednak o podstawową edukację syna².

O pierwszych krokach stawianych przez Kircha w świecie astronomii wiemy niewiele. Bez odpowiedzi pozostaje pytanie, skąd wzięło się jego zamiłowanie do obserwacji nieba. W liście do duńskiego astronoma Olausa Rømera (1644-1710) z 25 października 1703 r. pisał Kirch, że astronomią interesował się od młodzieńczych lat, jednak długo brakowało mu środków, by te zainteresowania rozwijać3.

W ustaleniu początków aktywności astronomicznej Kircha pomagają dwie wzmianki. Daniel Ernst Jablonski (1660-1741), prezentując w marcu 1700 r. Kircha jako najlepszego kandydata na stanowisko astronoma przyszłej akademii nauk, wskazywał, że uczony miał za sobą 40 lat doświadczenia jako astronom. Wnioskować z tego możemy, że z $1660 \mathrm{r}$. wiążą się początki jego działalności astronomicznej ${ }^{4}$ Sam Kirch w wysłanym 16 października 1705 r. liście do Gottfrieda Wilhelma Leibniza (1646-1716) wspominał o obserwacjach astronomicznych gromadzonych przez 42 lata $^{5}$. Oznaczałoby to, że w 1663 r. rozpoczął zapisywanie prowadzonych badań.

Równie mgliście zarysowują się początki pracy nad kalendarzami, które stały się w latach późniejszych źródłem utrzymania astronoma. Możemy je orientacyjnie wiązać z 1665 r. Wskazuje na to list od Nicolausa Schmidta (1606-1671) z 19/29 listopada 1665 r., który odsyłał Kirchowi jego „napisany” na 1666 r. kalendarz ${ }^{6}$. Najstarszy znany kalendarz autorstwa astronoma wydrukowany został na 1667 r. (Alt und Neu $J a h r=B u c h)$. Była to pierwsza sztuka serii, której nazwa, po różnych modyfikacjach, od 1674 r. utrwaliła się pod tytułem Christen= Jüden= und Türcken=Kalender, stając

2 J.G. Reinbeck, Die Stern=Kunst/ Nach ihrem Mißbrauch und rechten Gebrauch [...], Cölln an der Spree [b.r.], s. 21-22.

3 Die Korrespondenz des Astronomen und Kalendermachers Gottfried Kirch (1639-1710), t. 2, Briefe 1689-1709, red. K.-D. Herbst, Jena 2006, s. 461.

4 A. Harnack, Geschichte der Königlich Preussischen Akademie der Wissenschaften zu Berlin, t. 2, Urkunden und Actenstücke zur Geschichte der Königlich Preussischen Akademie der Wissenschaften, Berlin 1900, s. 63.

5 Die Korrespondenz, t. 2, s. 477.

6 K.-D. Herbst, Der Astronom Gottfried Kirch (1639-1710) im Vogtland, „Jahrbuch des Museums Reichenfels-Hohenleuben" 2001, z. 46, s. 96; idem, Die Kalender von Gottfried Kirch, [w:] Beiträge zur Astronomiegeschichte, t. 7, red. W.R. Dick, J. Hamel, Frankfurt am Main 2004 (Acta Historica Astronomiae, t. 23), s. 126-127; Die Korrespondenz des Astronomen und Kalendermachers Gottfried Kirch (1639-1710), t. 1, Briefe 16651689 , red. K.-D. Herbst, Jena 2006, s. 3. 
się najbardziej rozpoznawalną serią tego autora; po jego śmierci kontynuowano ją aż do 1788 r. $^{7}$

Brak wystarczającego materiału źródłowego nie pozwala na bliższe zarysowanie historii astronoma aż do dwudziestego szóstego roku życia. W listopadzie 1665 r. Kirch mieszkał w Vogtland, gdzie w miejscowości Langgrün pracował jako nauczyciel. 18/28 czerwca 1667 r. poślubił tam Marię, córkę Hansa Langa. Z tego związku 1/11 czerwca 1668 r. przyszedł na świat martwo urodzony pierwszy potomek. W 1668 r. zmienił Kirch miejsce nauczania na Neundorf ${ }^{8}$. Dokładnie nie wiadomo, kiedy para przeprowadziła się do położonego nieopodal Lobbenstein. Ich następne dziecko, Gottlieb, oddano do chrztu 16/26 lipca 1669 r. w tym właśnie mieście. 11/21 kwietnia 1671 r. Maria Kirch powiła kolejnego syna, Friedemanna, dziecko jednak kilka dni po porodzie zmarło i 18/28 kwietnia tego roku zostało pochowane. Czwarty syn urodził się martwy 28 lipca/7 sierpnia 1672 r. 24 września/4 października 1673 r. rodzina Kirchów powiększyła się o następne dziecko, syna Ehrenfrieda?.

Na 1673 r. opracował Kirch najstarszy znany obecnie egzemplarz Ziegeuner=Kalender, serii kalendarzowej pisanej pod pseudonimem Sibylla Ptolomaein ${ }^{10}$. Z okresu tego pochodzi także pierwsze pismo astronomiczne Kircha Stern=Lust, które prognozowało wschody i zachody planet między 1 października 1673 r. a 31 grudnia 1674 r. ${ }^{11}$ Skłonności do eksploracji nieba zaprowadziły uczonego w 1674 r. do Jana Heweliusza (1611-1687). Do gdańskiego obserwatorium trafił dzięki rekomendacji Erharda Weigla (1625-1699), jeńskiego profesora matematyki ${ }^{12}$. U Heweliusza, który jak pisał gubiński astronom w listach do żony, był dobrym, aczkolwiek wymagającym nauczycielem, pomagał w obserwacjach i obliczeniach ${ }^{13}$. Podróż edukacyjną kontynuował w 1675 r. w Królewcu, powracając najprawdopodobniej latem tego roku do Lobbenstein ${ }^{14}$.

Jeszcze przed przeprowadzką rodziny Kirchów do Lipska w 1676 r., w Lobbenstein urodził się 13/23 sierpnia Guthmann, kolejny syn uczonego ${ }^{15}$. Na semestr letni tego roku Kirch został przyjęty w poczet studentów Uniwersytetu Lipskiego ${ }^{16}$. Schronienie dla siebie, żony

7 Christen-, Juden- und Türken- Kalender für das Jahr 1667 verfaßt von Gottfried Kirch, red. K.-D. Herbst, Jena 2009 (Acta Calendariographica - Kalenderreihen, t. 1, z. 1), b.p.; K.-D. Herbst, Kirch, Gottfried, [w:] idem, Biobibliographisches Handbuch der Kalendermacher von 1550 bis 1750, www.presseforschung.uni-bremen. de/dokuwiki/doku.php?id=Startseite [dostęp 11.01.2021].

8 Idem, Neue Erkenntnisse zur Biographie von Gottfried Kirch, [w:] 300 Jahre Astronomie in Berlin und Potsdam. Eine Sammlung von Aufsätzen aus Anlaß des Gründungsjubiläums der Berliner Sternwarte, red. W.R. Dick, K. Fritze, Thun - Frankfurt am Main 2000 (Acta Historica Astronomiae, t. 8), s. 77-78; idem, Der Astronom Gottfried Kirch, s. 96.

9 Gottfried Kirch (1639-1710) - Astronom und Kalendermacher, gottfried-kirch-edition.de/?page_id=54 [dostęp 21.11.2020].

10 Dokładnie: „Sibylla Ptolomaein/eine Ziegeunerin von Alexandria aus Egypten”. Kalendarze pisał Kirch również pod pseudonimami: Georgius Fabricius, Jesaias Gräuf, Hipparchus, Johann Friedrich von Rosenfeld. K.-D. Herbst, Die Kalender von Gottfried Kirch, s. 117, 130-132, 139, 143-144; idem, Kirch, Gottfried, [w:] idem, Biobibliographisches Handbuch der Kalendermacher von 1550 bis 1750, www.presseforschung.uni-bremen.de/dokuwiki/doku.php?id=Startseite [dostęp 11.01.2021].

11 Idem, Der Astronom Gottfried Kirch, s. 97.

12 Idem, Neue Erkenntnisse, s. 72.

13 J.G. Reinbeck, op. cit., s. 22; Die Korrespondenz, t. 1, s. 7.

14 K.-D. Herbst, Neue Erkenntnisse, s. 72-73.

15 Die Korrespondenz, t. 1, s. Ixxxiii.

16 Die iüngere Matrikel der Universität Leipzig 1559-1809. Als Personen- und Ortsregister bearbeitet und durch Nachträge aus den Promotionslisten ergänzt, t. 2, Die Immatrikulationen vom Wintersemester 1634 bis zum Sommersemester 1709, red. G. Erler, Leipzig 1909, s. 218; K.-D. Herbst, Neue Erkenntnisse, s. 73. 
i trójki dzieci znalazł w Collegium Paulinum, w którym rodzina mieszkała od 14/24 grudnia 1676 r. ${ }^{17}$ 13/23 lipca 1677 r. Kirch stracił syna Guthmanna. Rodzina Kirchów powiększyła się następnie o syna Heilmanna, oddanego do chrztu 22 stycznia/1 lutego 1679 r. Jeszcze w tym samym roku 3/13 września zmarł sześcioletni Ehrenfried ${ }^{18}$.

Przenosiny do Lipska pozytywnie wpłynęły na rozwój aktywności naukowej Kircha. Zwiastowały one między innymi ożywienie publikacyjnej działalności astronoma. Drukiem ukazały się kolejne jego pozycje: zapowiedź zakrycia Marsa przez Księżyc i zaćmienia Słońca na 1676 r., obserwacje komety z kwietnia 1677 r., efekty badań gwiazdy zmiennej o Ceti (Mira) w gwiazdozbiorze Wieloryba z 1677 r. ${ }^{19}$ Na rok 1677 zachował się najstarszy znany egzemplarz Astronomischer Wunder=Kalender, lipskiej serii skierowanej do wszystkich miłośników astronomii ${ }^{20}$. Specyfika tego cieszącego się zainteresowaniem kalendarza polegała na ukierunkowaniu treści jego prognostyku na naukę o zjawiskach astronomicznych i rady, jak je obserwować. Ze schyłku 1677 r. pochodzą najstarsze znane zapisy obserwacji Kircha w formie dziennikowej. Dzienniki obserwacyjne będzie prowadził (z większą lub mniejszą regularnością) do końca życia, pozostawiając po sobie ogromną spuściznę w postaci 33 lat regularnych, dziennych obserwacji astronomiczno-meteorologicznych ${ }^{21}$.

Na potrzeby obserwacji zakrycia gwiazdy 6 wielkości w południowym rogu gwiazdozbioru Byka przez Saturna 7/17 stycznia 1679 r. Kirch opracował koncepcję mikrometru śrubowego. Mocowany w płaszczyźnie ogniskowej teleskopu przyrząd służył do mierzenia odległości kątowej między dwoma obiektami na niebie ${ }^{22}$. Informacje o mikrometrze upowszechnił astronom znacznie później. Pierwsze opisy historii, konstrukcji, specyfiki, zastosowania i szczegóły użycia instrumentu odnaleźć możemy dopiero w jego kalendarzach z lat dziewięćdziesiątych XVII w. ${ }^{23}$

17 Die Korrespondenz, t. 1, s. Ixxxi.

18 Gottfried Kirch (1639-1710) - Astronom und Kalendermacher, gottfried-kirch-edition.de/?page_id=54 [dostęp 21.11.2020].

19 Autorem wykazów astronomicznych publikacji Gottfrieda Kircha jest Klaus-Dieter Herbst. Zob. K.-D. Herbst, Astronomie um 1700. Kommentierte Edition des Briefes von Gottfried Kirch an Olaus Römer vom 25. Oktober 1703, Thun - Frankfurt am Main 1999 (Acta Historica Astronomiae, t. 4), s. 132-137; Die Korrespondenz des Astronomen und Kalendermachers Gottfried Kirch (1639-1710), t. 3, Übersetzungen, Kommentare, Verzeichnisse, red. K.-D. Herbst, Jena 2006, s. 651-661. Aktualne spisy pochodzą z portali: Gottfried Kirch (1639-1710) - Astronom und Kalendermacher, gottfried-kirch-edition.de/?page_id=61 [dostęp 21.11.2020]; K.-D. Herbst, Kirch, Gottfried, [w:] idem, Biobibliographisches Handbuch der Kalendermacher von 1550 bis 1750, www. presseforschung.uni-bremen.de/dokuwiki/doku.php?id=Startseite [dostęp 11.01.2021].

20 Idem, Die Kalender von Gottfried Kirch, s. 133-135.

21 Dzienniki obserwacyjne Gottfrieda Kircha znajdują są obecnie w Bibliotece Obserwatorium Paryskiego. Instytucja przechowuje pozycje astronoma z lat 1677-1710. Bibliothèque de I'Observatoire de Paris [BOP], B 3.1-6 G. Kirch, Journal autographe de ses observations, 1677-1710. W zbiorach biblioteki odnaleźć można również łacińskie tłumaczenia dzienników obejmujące lata 1684-1707. BOP, B 2.15-16 Observations de M. Kirch le père, traduites de l'allemand, 1684-1707. Odpisy dzienników z lat 1700-1709 znajdują się pod opieką Archiwum Berlińsko-Brandenburskiej Akademii Nauk. Archiv der Berlin-Brandenburgischen Akademie der Wissenschaften [ABBAW], NL Kirch, Nr. 1-5 Astronomische Observationes, 1700-1709.

22 G. Kirch, Christen = Jüden = und Türcken = Kalender/ Auf das Jahr Jesu Christi 1696, Nürnberg [b.r.], k. G, r-G v.

23 K.-D. Herbst, Die astronomischen Instrumente von Gottfried Kirch, [w:] Der Meister und die Fernrohre. Das Wechselspiel zwischen Astronomie und Optik in der Geschichte. Festschrift zum 85. Geburtstag von Rolf Riekher, red. J. Hamel, I. Keil, Frankfurt am Main 2007 (Acta Historica Astronomiae, t. 33), s. 209; J. Rogińska, Mikrometr śrubowy Gottfrieda Kircha - historia, konstrukcja i upowszechnienie w 1. poł. XVIII w., „Kwartalnik Historii Nauki i Techniki" t. 66, 2021, nr 3, s. 185-196. 
Kolejnym ważnym etapem w astronomicznej karierze Kircha był Coburg ${ }^{24}$, dokąd udał się 16/26 sierpnia 1680 r. Do miasta nie wpuszczono go od razu ze względu na panującą w Lipsku zarazę. Dopiero na początku września opuścił pobliską wieś, w której oczekiwał na zgodę na wjazd ${ }^{25}$. Ośmiomiesięczny pobyt w Coburgu zaznaczył się w biografii astronoma odkryciem 4/14 listopada 1680 r. komety. Obiekt, którego ruch na nieboskłonie śledził do 24 listopada/4 grudnia, wypatrzył Kirch za pomocą teleskopu o ogniskowej wynoszącej 2 stopy ${ }^{26}$. Szczegóły obserwacji, w tym badania prowadzone na zamku Ehrenburg, siedzibie Albrechta księcia Saksonii-Coburg (1648-1699), opisał Kirch w wydanej w następnym roku pracy Neue Himmels=Zeitung. W publikacji znalazły się również obserwacje powrotu komety między 15/25 grudnia 1680 r. a 10/20 lutego 1681 r., które interpretował mylnie jako pojawienie się drugiego obiektu tego typu ${ }^{27}$. W maju $1681 \mathrm{r}$. był już astronom z powrotem w Lipsku².

Pierwszy tom Ephemeridum Motuum Coelestium autorstwa Kircha został obliczony na $1681 \mathrm{r}$. Efemeryda była rodzajem publikacji tabelarycznej, zawierającej informacje o położeniu ciał niebieskich obliczonym z góry na dany moment ${ }^{29}$. Efemerydy Kircha utrzymały się na rynku wydawniczym przez ponad dziesięć lat (1681-1692)30. Odbywało się to przy sporym wysiłku uczonego, który sam musiał się zatroszczyć o znalezienie wydawcy, a niekiedy drukował na własny koszt ${ }^{31}$. Ze względu na użyteczność tej formy publikacji w praktyce obserwacyjnej efemerydy przysporzyły sporej popularności ich autorowi i przyczyniły się do budowania jego prestiżu w świecie astronomii. Efemerydy Kircha wieńczyły artykuły z obserwacjami astronomicznymi. I tak w drugim tomie, na 1682 r., zamieszczona została informacja o rozpoznaniu 1/11 września 1681 r. przez astronoma gwiazdy mgławicowej w gwiazdozbiorze Tarczy ${ }^{32}$.

W 1682 r. powstały w Lipsku „Acta Eruditorum”, pierwsze niemieckie czasopismo o charakterze naukowym, wydawane przez Ottona Menckego (1644-1707) ${ }^{33}$. Łacińskojęzyczny

24 Zmiana miejsca zamieszkania dawniej w historiografii tłumaczona była pojawieniem się w Lipsku zarazy. Jak wynika z nowych badań i koncepcji K.-D. Herbsta, wiązać się mogła z planami przekształcenia coburskiego gimnazjum w uniwersytet. W 1680 r. do władzy doszedł miłośnik astronomii, Albrecht książę Saksonii-Coburg. Wzmianki Kircha z jego pism astronomicznych i korespondencji obrazują nadzieje uczonego, liczącego na wsparcie przez księcia badań astronomicznych i założenia obserwatorium zob. K.-D. Herbst, Neue Erkenntnisse, s. 74-75; idem, Die Astronomie in der Mitte des 17. Jahrhunderts und ihre Förderung durch Ernst den Frommen in Gotha und Albrecht in Coburg, [w:] Ernst der Fromme (1601-1675). Staatsmann und Reformer. Wissenschaftliche Beiträge und Katalog zur Ausstellung, red. R. Jacobsen, H.-J. Ruge, Bucha bei Jena 2002 (Veröffentlichungen der Forschungsbibliothek Gotha, 39), s. 268-272.

25 Die Korrespondenz, t. 1, s. 69.

26 Rozpoznanie komety z 1680 r. (C/1680 V1) przez Gottfrieda Kircha uznawane jest za pierwsze teleskopowe odkrycie komety. G. W. Kronk, Cometography. A Catalog of Comets, t. 1, Ancient-1799, Cambridge 1999, s. 369; K.-D. Herbst, Zum 300. Todestag des Astronomen und Kalendermachers Gottfried Kirch, [w:] Gottfried Kirch (1639-1710) und die Berliner Astronomie im 18. Jahrhundert. Beiträge des Kolloquiums am 6. März 2010 in Berlin-Treptow, red. J. Hamel, Frankfurt am Main 2010 (Acta Historica Astronomiae, t. 41), s. 29.

27 G. Kirch, Neue Himmels=Zeitung [...], Nürnberg 1681, s. 21-53, 54-84.

28 Die Korrespondenz, t. 1, s. 107.

29 Y. Maeyama, Tables and Ephemerides, [w:] Encyclopedia of the Scientific Revolution. From Copernicus to Newton, red. W. Applebaum, New York 2005, s. 48.

30 K.-D. Herbst, Neue Erkenntnisse, s. 81.

31 Die Korrespondenz, t. 1, s. 111, 147.

32 G. Kirch, Stella nebulosa propè pedem borealem Ganymedis observata, Lipsiae, die 1. Sept. Anno 1681, [w:] idem, Annus II. Ephemeridum Motuum Coelestium Ad Annum Aerae Christianae M. DC. LXXXII [...], Lipsiae [b.r.], k. $F_{2}$ v. Obiekt sklasyfikowano w katalogu Charlesa Messiera (1730-1817) i umieszczono pod numerem M11. K.G. Jones, Messier's Nebulae and Star Clusters, Cambridge 1991, s. 80.

33 D. Döring, Acta Eruditorum, [w:] Zur Alltagsgeschichte der Philosophie in Leipzig, red. K.-D. Eichler, U.J. Schneider, Leipzig 2004 (Leipziger Schriften zur Philosophie, t. 18), s. 32. 
periodyk był najważniejszym miejscem, w którym Kirch regularnie publikował swoje obserwacje. Trafiły tam na przykład jego obserwacje komety z 1682 r. Nie zrezygnował przy tym z wydawania własnych broszur. W ten sposób ukazały się drukiem obserwacje wspomnianej komety z 1682 r., następnie badania komety z 1683 r. czy w 1684 r. gwiazdozbiór Gladii Electorales Saxonici34. Część obserwacji astronom ogłaszał we wspomnianych już efemerydach, wiele ponadto trafiało $w$ formie dodatku do pisanych przez niego kalendarzy.

Warunki pracy, jakie posiadał Kirch, dalekie były od ideału. Regularne, dzienne obserwacje wykonywał w prywatnej strefie mieszkania. Lipskie lokum nie nadawało się do tego zbyt dobrze, co unaoczniają liczne narzekania astronoma na brak wygodnego miejsca do pracy. Przy większych i ważniejszych wydarzeniach na niebie decydował się uczony na obserwacje z wież Fürstenhaus czy kościoła św. Tomasza w Lipsku35. Obserwacje prowadził za pomocą zakupionych lub samodzielnie złożonych instrumentów. Na łamach swoich druków często skarżył się zarówno na złe warunki obserwacyjne, jak i słabe instrumentarium.

Kirch należał do grona bardzo produktywnych autorów kalendarzy swoich czasów. Ten stan rzeczy długo nie był rozpoznany w historiografii. Badaniom nie sprzyjało nie tylko wielość miejsc druku jego pozycji (Altenburg, Annaberg, Wrocław, Brzeg, Gdańsk, Erfurt, Jena, Królewiec, Lipsk, Norymberga, Stargard, Zeitz, Żytawa), lecz przede wszystkim to, że były publikowanie pod cudzymi nazwiskami ${ }^{36}$. Kirch pisał kalendarze nie tylko pod pseudonimami, lecz również pod nazwiskami zmarłych autorów, których serie kalendarzowe przejął. Na przykład po śmierci Christopha Richtera (1618-1680) kontynuował prowadzenie dwóch jego kalendarzy, Jahres=Zeiger Schreib=Kalender i Gesprächs=Kalender ${ }^{37}$. Skalę działalności Kircha dla tego okresu uzmysławiają ustalenia Herbsta, któremu tylko dla 1685 r. udało się odnaleźć i zidentyfikować aż 13 różnych gatunków kalendarzy tego autora ${ }^{38}$.

Długotrwałe i uważne obserwacje nieba pozwoliły Kirchowi w 1686 r. odkryć gwiazdę zmienną $\chi$ Cygni. Dostrzeżenie w gwiazdozbiorze Łabędzia gwiazdy zmiennej było efektem obserwacji, które astronom prowadził między 1/11 lipca a 9/19 października tego roku $^{39}$. Wagę dokonania podkreśla fakt, że po odkrytej w 1596 r. przez Davida Fabriciusa (1564-1617) o Ceti i rozpoznanej w 1669 r. $\beta$ Persei (Algol) był to trzeci znany tego typu obiekt w tamtych czasach ${ }^{40}$.

Jeszcze innym aspektem działalności astronomicznej Kircha było tworzenie nowych gwiazdozbiorów. Po tym jak w 1684 r. Gladii Electorales Saxonici trafiły do „Acta Eruditorum", zaproponowane zostały przez astronoma w 1688 r. na łamach tego czaso-

34 Gottfried Kirch (1639-1710) - Astronom und Kalendermacher, gottfried-kirch-edition.de/?page_id=61 [dostęp 21.11.2020].

35 Die Korrespondenz, t. 1, s. 93.

36 K.-D. Herbst, Die Kalender von Gottfried Kirch, s. 117-118.

37 Kirch kontynuował również prowadzenie kalendarzy po takich autorach jak: Nicolaus Schmidt, Johann Neubarth oraz Valentin Hancke (młodszy); K.-D. Herbst, Die Kalender von Gottfried Kirch, s. 140-142; idem, Kirch, Gottfried, [w:] idem, Biobibliographisches Handbuch der Kalendermacher von 1550 bis 1750, www.presseforschung.uni-bremen.de/dokuwiki/doku.php?id=Startseite [dostęp 11.01.2021].

38 Idem, Die Kalender von Gottfried Kirch, s. 116-117.

39 G. Kirch, Stellae In Cygno Fixae, Alternis Temporibus visae \& invisae, vicissitudines Lipsiae observatae a Godofredo Kirchio, „Acta Eruditorum” 1687, nr 11, s. 647-648.

40 J. Hamel, Geschichte der Astronomie. Von den Anfängen bis zur Gegenwart, Basel - Boston - Berlin 1998, s. 211 . 
pisma kolejne dwa gwiazdozbiory: Pomum Imperiale, konstelacja ustanowiona na cześć Leopolda I Habsburga (1640-1705), oraz Sceptrum Brandenburgicum, honorujące brandenburskich elektorów ${ }^{41}$. W Christen = Jüden= und Türcken=Kalender na 1690 r. przedstawił jeszcze jeden nowy gwiazdozbiór Corona Hungarica na cześć Józefa I Habsburga (1678-1711) ${ }^{42}$. Propozycje Kircha nie spotkały się z przychylnością kolejnych pokoleń astronomów i żaden z jego gwiazdozbiorów nie zachował się we współczesnej uranografii.

Syna Gottlieba, który w 1688 r. zdobył na Uniwersytecie Lipskim tytuł Baccalaureus Artium, wysłał Kirch 29 maja/8 czerwca 1690 r. w podróż do Warszawy, aby tam dzięki pośrednictwu polskiego jezuity i matematyka Adama Adamandego Kochańskiego (16311700) spotkał się $z$ działającym w Chinach jezuickim misjonarzem Claudiem Filippem Grimaldim (1638-1712) i tym samym zainicjował wymianę korespondencji43. Podczas jego nieobecności stan zdrowia żony astronoma zaczął się pogarszać. Maria Kirch zmarła 20/30 czerwca 1690 r. ${ }^{44}$, zostawiając astronoma z dwójką małych dzieci, jedenastoletnim Heilmannem i siedmioletnią Theodorą ${ }^{45}$.

Życie w saksońskim mieście stawało się dla Kircha, zwolennika pietyzmu, coraz bardziej uciążliwe przez nasilający się konflikt ortodoksyjnych teologów i pietystów ${ }^{46}$. 20/30 marca 1690 r. wezwano astronoma do złożenia wyjaśnień przed konsylium Uniwersytetu Lipskiego w sprawie organizacji i udziału w kolegiach pietystów ${ }^{47}$. 4/14 września 1691 r. przesłuchiwano go ponownie w związku z dochodzeniem przeciwko Samuelowi Vogtowi ${ }^{48}$. W liście do przebywającego w Amsterdamie syna Gottlieba z 26 września/6 października 1691 r. pisał, że był „wszędzie w Lipsku prześladowany”, wspominał o „rozjątrzonych antypietystach" i donosił o panującym w mieście niepokoju ${ }^{49}$.

W związku z panującymi w Lipsku nastrojami zrodził się plan zmiany miejsca zamieszkania. Astronom rozpatrywał możliwość przeniesienia się do Gubina, pod uwagę brał także wyjazd do Halle ${ }^{50}$. Ostatecznie jednak postanowił wrócić do rodzinnego miasta. O zamiarze osiedlenia się w Gubinie i powrocie do swojej ojczyzny donosił po 23 stycznia/2 lutego 1692 r. w liście do norymberskiego astronoma Johanna Philippa von Wurzelbaua (1651$1725)^{51}$.

41 D. Wattenberg, Dynastien und Astrognosie, „Die Sterne” r. 38, 1962, z. 11/12, s. 230-231; D.J. Warner, The Sky Explored. Celestial Cartography 1500-1800, New York 1979, s. 137-138; J. Dobrzycki, J. Włodarczyk, Historia naturalna gwiazdozbiorów, Warszawa 2002, s. 69-71; N. Kanas, Star Maps. History, Artistry, and Cartography, Berlin - Heidelberg - New York 2007, s. 127-130; J. Włodarczyk, M. Jasiński, Jan III Sobieski i uranografia polityczna XVII stulecia, [w:] Primus Inter Pares. Pierwszy wśród równych, czyli opowieść o królu Janie III, red. D. Walawender-Musz, Warszawa 2013, s. 140-145.

42 Die Korrespondenz, t. 3, s. 294

43 BOP, B3.4, s. 256; K.-D. Herbst, Wer half dem Astronomen Gottfried Kirch?, [w:] Unsichtbare Hände. Zur Rolle von Laborassistenten, Mechanikern, Zeichnern u. a. Amanuenses in der physikalischen Forschungs- und Entwicklungsarbeit, red. K. Hentschel, Diepholz - Stuttgart - Berlin 2008, s. 57-58.

44 BOP, B3.4, s. 259.

45 Do chrztu oddano Theodorę 17/27 IV 1683 r. Die Korrespondenz, t. 1, s. Ixxxiii.

46 K.-D. Herbst, Zum 300. Todestag des Astronomen, s. 32.

47 Przebieg przesłuchania zrelacjonował Kirch w swoim dzienniku na 1690 r. BOP, B3.4, s. 241-242.

48 D. Döring, Der Briefwechsel zwischen Gottfried Kirch und Adam A. Kochanski 1680-1694. Ein Beitrag zur Astronomiegeschichte in Leipzig und zu den deutsch-polnischen Wissenschaftsbeziehungen, Berlin 1997 (Abhandlungen der Sächsischen Akademie der Wissenschaften zu Leipzig, Philologisch-Historische Klasse, t. 74, z. 5), s. 24-25.

49 Die Korrespondenz, t. 2, s. 106-108.

50 Ibid., s. $106-108$

51 Ibid., s. 123 
Decyzja o wyjeździe podjęta została na długo przed powtórnym ożenkiem uczonego. Drugą wybranką Gottfrieda Kircha była Maria Margaretha Winckelmann, urodzona 15/25 lutego 1670 r. w Panitzsch koło Lipska. Jej ojcem był Matthias Winckelmann (16301682), pastor w Panitzsch, Sommerfeld i Alten, a matką Maria Töllner (zm. 1683) ${ }^{52}$. Po śmierci rodziców Maria Margaretha trafiła pod opiekę Justinusa Töllnera (1656-1718). Panitzsch położone było niedaleko Sommerfeld, gdzie mieszkał Christoph Arnold (16501695) ${ }^{53}$. Arnold, nazywany „chłopskim astronomem” (Bauernastronom), znajdował się od ok. 1686 r. w bliskiej, opierającej się na wymianie informacji pogodowych i astronomicznych, relacji z Kirchem ${ }^{54}$. Plany małżeńskie według listu uczonego z 14/24 marca 1692 r. do Augusta Hermanna Franckego (1663-1727) były już ustalone ${ }^{55}$. Para stanęła na ślubnym kobiercu 8/18 maja 1692 r. w Panitzsch ${ }^{56}$.

20/30 października 1692 r. rodzina Kirchów (Gottfried z żoną i córką Theodorą) podróżowała do Gubina; dotarła do miasta 24 października/3 listopada ${ }^{57}$. Gubińska księga wpisów do prawa miejskiego donosi pod datą 1/11 listopada 1692 r. o złożeniu obowiązku obywatelskiego przez astronoma ${ }^{58}$. W mieście kupił Kirch dom i ogród ${ }^{59}$. Prowadzenie dziennika obserwacyjnego kontynuował w Gubinie od 23 listopada/3 grudnia ${ }^{60}$.

Osiedlenie się w rodzinnym mieście nie sprzyjało aktywności naukowej Kircha. Od 1692 r. diametralnie spadła liczba meldunków obserwacyjnych w jego dziennikach. Skutkowało to zmniejszeniem obecności prac astronomicznych na rynku wydawniczym oraz niewielką liczbą artykułów publikowanych w "Acta Eruditorum”. Rozstając się z Lipskiem, Kirch stracił bezpośredni kontakt nie tylko z tamtejszym środowiskiem uczonych, lecz przede wszystkim z wydawcami. Przestały się ukazywać jego efemerydy, których ze względu na brak środków już nie drukowano; zachowały się niedokończone rękopisy na lata 1693 i $1694^{61}$. Astronom stracił także w tym okresie dochód z niektórych swoich kalendarzy ${ }^{62}$.

Dostrzegalny na płaszczyźnie badawczej regres stał w opozycji do kwitnącego życia rodzinnego i systematycznego zwiększania się liczby członków gospodarstwa domowego. Pierwszym dzieckiem z nowego związku astronoma była Maria, oddana do chrztu 12/22 maja 1693 r. ${ }^{63}$ 14/24 grudnia 1694 r. przyszedł na świat pierwszy i jedyny syn z drugiego małżeństwa. Christfried, bo tak dano na imię chłopcu, ochrzczony został

52 Die Korrespondenz, t. 1, s. Ixxxiii.

53 A. des Vignoles, Eloge de Madame Kirch, à I'occasion de laquelle on parle de quelques autres Femmes \& d'un Paisan Astronomes, „Bibliotheque germanique ou Histoire litteraire de l'Allemagne, de la Suisse, et des Pays du Nord" t. 3, 1721 [dr. 1722], s. 168-173.

54 BOP, B3.3, n 81, s. 25, 267, 372; B3.4, s. 99, 107, 184.

55 Die Korrespondenz, t. 2, s. 134.

56 J. G. Reinbeck, op. cit., s. 25. W liście do Kochańskiego z 20/30 IV 1694 r. podaje Kirch jako miejsce wstąpienia w związek małżeński Lipsk. Die Korrespondenz, t. 2, s. 184.

57 BOP, B3.4, s. 313.

58 Brandenburgisches Landeshauptarchiv Potsdam, Rep. 8 Stadt Guben - Akten (1430-1954), Sig. 6. Bürgerschaftsbuch 1638-1702, s. 484.

59 Die Korrespondenz, t. 2, s. 184. W liście do Kochańskiego z 20/30 IV 1694 r., z którego pochodzą informacje o zakupie domu i ogrodu, wspominane zostało również nabycie winnicy; ta ostatnia wzmianka nie znajduje jak na razie żadnego innego potwierdzenia w źródłach.

60 BOP, B3.4, s. 315.

61 K.-D. Herbst, Zum 300. Todestag des Astronomen, s. 32-33.

62 Die Korrespondenz, t. 2, s. 185.

63 Archiwum Państwowe w Zielonej Górze [APZG], zesp. 129 Akta metrykalne Gubin/Guben - parafie ewangelickie, sygn. 6 Tauf-Register, s. 587. 
19/29 grudnia ${ }^{64}$. Następnie 14/24 kwietnia 1697 r. urodziła się Christina, która otrzymała chrzest 18/28 kwietnia ${ }^{65}$. Niedługo po tym, 5/15 sierpnia 1697 r., zmarła czteroletnia Maria ${ }^{66}$. Dwa lata później rodzina Kirchów powiększyła się o kolejną córkę. Sophia trzymana była do chrztu 28 marca/7 kwietnia 1699 r. przez Urlicha Juniusa (1670-1726), goszczącego $\mathrm{w}$ tym czasie $\mathrm{u}$ astronoma ${ }^{67}$. Niemowlę zmarło cztery tygodnie później (26 kwietnia/6 maja) ${ }^{68}$.

Widoki na poprawę pozycji Kircha przyniósł schyłek XVII w. W 1697 r. zrodził się pomysł, wspierany przez Zofię Charlottę Hanowerską (1668-1705), żonę elektora Brandenburgii, utworzenia w Berlinie obserwatorium. Do dyskusji w tej sprawie włączono Gottfrieda Wilhelma Leibniza, który zainicjował jednocześnie rozmowy na temat urządzenia akademii69. Jak daleko idące były to wówczas plany, świadczą listy Johanna Jakoba Chuno (1661-1715) i Johanna Gebharda Rabenera (1632-1701) z pierwszymi nieoficjalnymi ofertami, którymi starano się zainteresować Kircha. 9/19 października 1697 r. Chuno informował o możliwości powołania uczonego do przyszłego obserwatorium ${ }^{70}$. Złożona przez Rabenera 9/19 października 1697 r. wstępna oferta obejmowała darmowe mieszkanie i 300 talarów pensji ${ }^{71}$.

W tym czasie Kircha starano się zainteresować jeszcze inną inicjatywą: powołanym 27 lipca 1697 r., dzięki staraniom Erharda Weigla, Collegium Artis Consultorum ${ }^{72}$. W liście z 9/19 października 1697 r. Chuno sugerował, aby gubiński uczony wstrzymał się z przyjęciem zaoferowanego mu przez Weigla miejsca, ponieważ przeprowadzka z rodziną do Norymbergi (siedziby instytucji) byłaby nie tylko droga, lecz też uciążliwa. Rabener podobnie radził nie spieszyć się z decyzją, tylko lawirowaćp ${ }^{73}$. Szczegóły prób pozyskania astronoma dla przedsięwzięcia, jak również powody, dla których inicjatywa Weigla nie doczekała się pełnej realizacji, wymagają dalszych badań.

W związku z wydarzeniami na berlińskim dworze w grudniu 1697 r. i aresztowaniem Eberharda von Danckelmanna (1643-1722) wszelkie działania związane z powstaniem obserwatorium zarzucono. Zamiaru nie zaniechano jednak całkowicie. Był on rozwijany w kolejnych latach korespondencyjnie przez kaznodzieję dworskiego Daniela Ernsta Jablonskiego, który w marcu 1698 r. rozpoczął wymianę myśli z Leibnizem ${ }^{74}$. Impuls do dalszych działań przyniosła tocząca się u schyłku XVII w. debata nad reformą kalendarza i wejście w życie w 1700 r. tzw. „ulepszonego kalendarza”75. Na dalszy rozwój zda-

Ibid., s. 606; A. des Vignoles, Eloge de M. Kirch le Fils, Astronome de Berlin, „Journal littéraire d'Allemagne, de Suisse et du Nort" t. 1, 1741, s. 305.

65 Deutsche Meteorologische Bibliothek [DMB], Sign. I B 1 M.M. Kirch, Zu Gottes Nahmen Wiederums neu angefangen die Tägliche=Beschreibung des Wetters Anno 1697, 24. April; APZG, sygn. 6, s. 629.

66 APZG, zesp. 129 Akta metrykalne Gubin/Guben - parafie ewangelickie, sygn. 7 Todten-Register vol. IV Jahrgang 1673-1743, s. 104.

67 Ibid., sygn. 6 , s. 648

68 Ibid., sygn. 7, s. 110 .

69 Leibniz und seine Akademie. Ausgewählte Quellen zur Geschichte der Berliner Sozietät der Wissenschaften 1697-1716, red. H.-S. Brather, Berlin 1993, s. 31.

70 Die Korrespondenz, t. 2, s. 239.

71 Ibid., s. 241.

72 Leibniz und seine Akademie, s. 37-38.

73 Die Korrespondenz, t. 2, s. 240, 241.

74 Leibniz und seine Akademie, s. 31-33.

75 W protestanckich krajach Rzeszy nie zaakceptowano ustanowionej w 1582 r. przez papieża Grzegorza XIII reformy kalendarza. Stworzony w konsekwencji podwójny system naliczania czasu w cesarstwie według starego 
rzeń największy wpływ wywarł Leibniz, który inspirując się projektem Weigla utrzymania Collegium Artis Consultorum z publikacji kalendarzy oraz saksońskim monopolem wydawniczym, stworzył zaplecze dla finansowania planowanych już od dłuższego czasu w Berlinie obserwatorium i towarzystwa naukowego ${ }^{76}$.

W marcu 1700 r. zgodę na powstanie instytucji wyraził Fryderyk III, elektor Brandenburgii ${ }^{77}$. Z rezydującym w Gubinie astronomem skontaktowali się następnie Rabener (20 marca) i Chuno (23 marca), oferując stanowisko pracy w przyszłym obserwatorium z roczną pensją 500 talarów $^{78}$. W celu dopełnienia formalności Kirch złożył wizytę w Berlinie w kwietniu ${ }^{79}$. W ten sposób na dwa miesiące przed oficjalnym założeniem towarzystwa, zaraz po tym, jak 10 maja wydano edykt kalendarzowy ${ }^{80}, 18$ maja nominowano oficjalnie Gottfrieda Kircha na stanowisko z tytułem Astronomus ordinarius ${ }^{81}$.

Podpisanie dyplomu założycielskiego Towarzystwa Nauk (Societas Scientiarum), początkowo zaplanowane na 26 czerwca, przesunięto na 11 lipca ${ }^{82}$. Fryderyk III, który w przededniu sięgnięcia po koronę pruską demonstrował tym aktem polityczną władzę, został protektorem towarzystwa. Prezydentem mianowano 12 lipca 1700 r. Leibniza, a wiceprezydentem 15 lipca Jablonskiego ${ }^{83}$. Na wzór angielski korpusem towarzystwa zostało konsylium, w którego skład według „Instrukcji generalnej” (11 lipca 1700 r.) wejść miały osoby zaangażowane w proces powstania instytucji ${ }^{84}$. W ten sposób grono ojców założycieli zabezpieczyło swoją pozycję w strukturach władzy. W efekcie wyjściowy zespół stworzyli Jablonski i Chuno. W dalszej perspektywie jego poczet zasilili Kirch oraz wybrany 6 października 1700 r. na sekretarza Johann Theodor Jablonski (1654-1731)

(kalendarz juliański) i nowego stylu (kalendarz gregoriański) stał się utrapieniem w życiu społeczno-gospodarczym. Dalej aktualny pozostawał także problem błędu kalendarza juliańskiego, w szczególności zauważalny w datacji świąt Wielkanocy, stąd zagadnienie jego poprawy włączono w latach osiemdziesiątych XVII w. w porządek obrad stanów ewangelickich Rzeszy (Corpus Evangelicorum). 23 IX/3 X 1699 r. postanowiły one o reformie, ustanawiając tzw. ulepszony kalendarz (Verbesserte Calender). „Poprawiony kalendarz" wszedł w życie 18 II 1700 r. wraz z opuszczeniem 11 dni i przejściem na dzień 1 III 1700 r. J. Hamel, Erhard Weigel und die Kalenderreform des Jahres 1700, [w:] Erhard Weigel - 1625 bis 1699. Barocker Erzvater der deutschen Frühaufklärung. Beiträge des Kolloquiums anläßlich seines 300. Todestages am 20. März 1999 in Jena, red. R. E. Schielicke, K.-D. Herbst, S. Kratochwil, Thun - Frankfurt am Main 1999 (Acta Historica Astronomiae, t. 7), s. 149; idem, Wissenschaftsförderung und Wissenschaftsalltag in Berlin 1700-1720 - dargestellt anhand des Nachlasses des ersten Berliner Akademieastronomen Gottfried Kirch und seiner Familie, "Sitzungsberichte der Leibniz-Sozietät" t. 55, 2002, z. 4, s. 61-62.

76 Leibniz und seine Akademie, s. 41.

77 Ibid., s. 46.

78 Die Korrespondenz, t. 2, s. 394-396.

79 A. Harnack, op. cit., s. 85.

80 Patent, nawiązując do przeprowadzonej reformy kalendarza, według której w szczególności święto Wielkanocy wyznaczane miało być na podstawie obserwacji astronomicznych, składał na ręce przyszłego Towarzystwa Nauk zadanie poprawnego opracowywania drukowanych kalendarzy. Dokument przyznawał towarzystwu monopol na obliczanie, przygotowywanie i dystrybucję kalendarzy na wszystkich obszarach panowania elektora Brandenburgii. A. Harnack, op. cit., s. 87-89.

81 ABBAW, PAW (1700-1811), I-III-1 Acta betr. die Ernennung und Besoldung der Protektoren, Präsidenten, Direktoren, des Fiskals, des Secretars, des Bibliothekars, der Astronomen und Kassenrendanten bei der Societät sowie der Professoren beim Collegio Medico-Chirurgico, 1700-1731, k. 8r-9r.

82 Leibniz und seine Akademie, s. 85.

83 E. Amburger, Die Mitglieder der Deutschen Akademie der Wissenschaften zu Berlin 1700-1950, Berlin 1950, s. 1, 3, 4. Spotykane w historiografii nazwy tych stanowisk to również: prezes i wiceprezes, przewodniczący i wiceprzewodniczący.

84 A. Harnack, op. cit., s. 105-106.

85 H.-S. Brather, Leibniz und das Konzil der Berliner Sozietät der Wissenschaften, „Studia Leibnitiana. Zeitschrift für Geschichte der Philosophie und der Wissenschaften" 1990, z. spec. 16, s. 219-221, 225. Rabener, który również był zaangażowany w powstanie towarzystwa, zmarł 29 I 1701 r. E. Amburger, op. cit., s. 10. 
Gubin opuściła rodzina Kirchów parę miesięcy po narodzinach Johanny, oddanej do chrztu 20 maja 1700 r. ${ }^{86}$ Maria Margaretha Kirch wraz z dziećmi dotarła do Berlina 3 sierpnia $1700 r^{87}$ Akt nominacji Kircha oprócz informacji o 500 talarach rocznego dochodu zawierał także obietnicę zapewnienia mu zakwaterowania ${ }^{88}$. Przez pierwsze lata towarzystwo wywiązywało się z tego postanowienia, opłacając wynajmowane przez uczonego lokum. Zamieszkano w Dorotheenstadt, w mieście, które dopiero w 1709 r. włączone zostało w granice Berlina ${ }^{89}$. Na początku rodzina Kirchów wprowadziła się do ciasnego, niewygodnego i niesprzyjającego prowadzeniu obserwacji lokalu ${ }^{90}$. Pierwszą, nienadającą się do prac astronomicznych kwaterę opuścili między 2 a 16 kwietnia 1701 r., przenosząc się do innego wynajmowanego w Dorotheenstadt mieszkania ${ }^{91}$.

Nominacja na pierwszego astronoma berlińskiego towarzystwa niewiele zmieniła w praktyce domowych obserwacji ze względu na przeciągający się okres budowy obserwatorium. Kirch dalej spoglądał w niebo z izb wynajmowanego mieszkania, strychu lub dziedzińca. Nie polepszyło się również instrumentarium astronoma. W pierwszych latach istnienia zdało się towarzystwo prawie całkowicie na prywatną kolekcję Kircha. Według ustaleń Herbsta do opuszczenia Gubina latem 1700 r. astronom miał w swoich zbiorach: 16 teleskopów optycznych (od 1,5 do 28 stóp), dwie perspektywy, mosiężny kwadrant, trzy mikrometry śrubowe i astrolabium ${ }^{92}$. Towarzystwo uzupełniło te zbiory tylko paroma nabytkami, w tym pozyskanym z elektorskiego gabinetu osobliwości rzymskim teleskopem o ogniskowej 18 stóp, konstrukcji Giuseppego Campaniego (1635-1715), przekazanym astronomowi 7 września 1700 r. $^{93}$

Najważniejszym realizowanym na rzecz towarzystwa zadaniem Kircha było pisanie kalendarzy. Wydawane anonimowo, były podstawowym źródłem utrzymania berlińskiej instytucji. W pierwszej dekadzie (1701-1710) zysk z realizacji monopolu kalendarzowego wyniósł $97,7 \%$ całości dochodu towarzystwa ${ }^{94}$. Mając na uwadze wiek Kircha, który przyjmowany był do towarzystwa, gdy wkraczał w 61 rok życia, sprawowanie tak ważnej dla egzystencji całego przedsięwzięcia funkcji postanowiono zabezpieczyć ${ }^{95}$, dając mu do pomocy adiunkta Johanna Heinricha Hoffmanna (1669-1716), mianowanego w lutym $1701 \mathrm{r}^{96}$

Przy okazji obserwacji komety, którą na niebie dostrzegła 21 kwietnia 1702 r. Maria Margaretha Kirch ${ }^{97}$, udało się rozpoznać jej mężowi koleją gwiazdę mgławicową. Odkryta została 5 maja 1702 r. w gwiazdozbiorze Węża ${ }^{98}$. Obserwacje komety, jak i informacje

87 DMB, Sign. I B 1 M.M. Kirch, Gewitter=Aufzeichnung im Jahr 1710, 3. Aug.

88 ABBAW, PAW (1700-1811), l-III-1, k. 8v-9r.

89 Leibniz und seine Akademie, s. 3-6.

90 DMB, Sign. I B 1 [M.M. Kirch] M.M.K., Wetter=Buch 1701, b.p.

91 Ibid., s. 26.

92 K.-D. Herbst, Die astronomischen Instrumente, s. 218.

93 BOP, B3.5, n 81, A, s. 13-14; ABBAW, NL Kirch, Nr. 1, s. 8-9; J. Hamel, Wissenschaftsförderung, s. 80.

94 Obliczenia własne na podstawie ksiąg rachunkowych z lat 1701-1710; ABBAW, PAW (1700-1811), I-XVI:66-75 Hauptrechnung über Einnahme und Ausgabe bei der Kgl. Societät der Wissenschaften, geführt von Johann Theodor Jablonski, 1701-1710.

95 ABBAW, PAW (1700-1811), I-III-1, k. 8v; A. Harnack, op. cit., s. 60, 65.

96 ABBAW, PAW (1700-1811), I-IV-6 Protocollum concilii Societatis, 1700-1720, k. 2r.

97 DMB, Sign. I B 1 [M.M. Kirch], Wetter=Buch 1702. Darinnen auff geschrieben, wie die Witterung dieses Jahres sich täglich verhalten, s. 29.

98 Informacje o gwieździe mgławicowej zamieścił Kirch w artykułach poświęconych komecie z 1702 r. G. Kirch, Godofredi Kirchii Observationes Cometae Novi, habitae Berolini a. d. 21 April. 1702, „Acta Eruditorum” 1702, 
o obiekcie wysłał uczony jeszcze w tym samym roku do „Acta Eruditorum”99. W historiografii zagranicznej w szczególności ten wątek kariery astronoma budzi kontrowersje z powodu „utajnienia" wkładu żony w pierwszych relacjach, jakie ukazały się z obserwacji komety. W tym miejscu wyjaśnić należy, że, po pierwsze, za odkrywców komety uznaje się obecnie dwóch Włochów (Giacoma Filippa Maraldiego i Francesca Bianchiniego) ${ }^{100}$. Po drugie, informacja o roli żony została upubliczniona w późniejszym artykule do „Miscellanea Berolinensia". Ze względu na przedłużający się czas druku pisma artykuł ujrzał światło dzienne dopiero w 1710 r. ${ }^{101}$

Rodzina Kirchów powiększyła się 24 lipca 1703 r. o kolejne i ostatnie już dziecko, córkę Margarethę ${ }^{102}$. Na 1704 r. opracował Kirch wydane drukiem tablice wejścia pierwszego satelity w cień Jowisza i wyjścia z jego cienia. W 1704 r. ukazały się ponadto w periodyku Akademii Nauk w Paryżu opracowane przez uczonego wyniki obserwacji zaćmienia Księżyca z 22-23 lutego 1701 r. ${ }^{103}$ Przełom 1704 i 1705 r. był dla rodziny Kirchów kryzysowym momentem ze względu na chorobę astronoma, która prawie na rok wyłączyła go z wielu aktywności, także naukowych ${ }^{104}$.

Budowa obserwatorium okazała się długim procesem. Na miejsce powstania obserwatorium upatrzono środkowy pawilon Neuer Marstall w Dorotheenstadt. Obiekt postanowiono przystosować do przyszłych prac astronomicznych i podwyższyć, dobudowując piętra ${ }^{105}$. Pierwszy etap, rozpoczęty na przełomie lata i jesieni 1700 r., zwieńczono w 1704 r. osiągnięciem stanu surowego. W 1706 r. ruszyły dalsze prace, w budynku wstawiono okna ${ }^{106}$. Na rok ten przypadają pierwsze badania astronomiczne rodziny Kirchów w niegotowym jeszcze gmachu towarzystwa. Pierwszą większą obserwację przeprowadzono tam 27-28 kwietnia 1706 r. podczas zaćmienia Księżyca ${ }^{107}$.

W 1708 r. za kwotę 2100 talarów towarzystwo wykupiło sąsiadujący z obserwatorium budynek z przeznaczeniem na dom astronoma. Do nowego lokum rodzina Kirchów rozpoczęła przeprowadzkę 4 kwietnia ${ }^{108}$. Na moment ten przypada w dziennikach astronoma zintensyfikowanie wizyt w obserwatorium oraz fala pokazowych obserwacji i odwiedzin ważnych osobistości. Przykładowo tuż po przeprowadzce 15 kwietnia zawitał tam kronprinz Fryderyk Wilhelm (1688-1740) ${ }^{109} .3$ lutego 1709 r. uczony zanotował, że w trakcie oglądania plam na Słońcu obecni byli prezydent Leibniz i profesor Sebastian Gottfried Starke (1668-1710), a towarzyszył im adiunkt Hoffmann ${ }^{110}$.

nr 6, s. 258; idem, De cometa Anno 1702. Berolini observato, "Miscellanea Berolinensia ad incrementum scientiarum, ex scriptis Societati Regiae Scientarum” [„Miscellanea Berolinensia”] t. 1, 1710, s. 215. Obiekt sklasyfikowano w katalogu Charlesa Messiera i umieszczono pod numerem M5. K.G. Jones, op. cit., s. 66.

99 G. Kirch, Godofredi Kirchii Observationes Cometae Novi, s. 256-258.

100 G.W. Kronk, op. cit., s. 388.

101 G. Kirch, De cometa Anno 1702, s. 213.

102 DMB, Sign. I B 1 [M.M. Kirch] M.M.K., 1703 Tägliche Gewitter Observation auffgeschrieben in Berlin, sonderlich in der Dorotheen=Stadt, s. 50 .

103 Gottfried Kirch (1639-1710) - Astronom und Kalendermacher, gottfried-kirch-edition.de/?page_id=61 [dostęp 21.11.2020].

104 J.G. Reinbeck, op. cit., s. 28.

105 A. Harnack, op. cit., s. 137-138.

106 Leibniz und seine Akademie, s. 386-387.

107 BOP, B2.16, $\mathrm{n}^{\circ} 85,8, \mathrm{~A}, 28$. April.

108 BOP, B3.6, n 82, B, s. 76. ABBAW, PAW (1700-1811), I-XVI-73, s. 30.

109 DMB, Sign. I B 1 [M.M. Kirch], Gewitter Observationes 1708, 15. April; Die Korrespondenz, t. 2, s. 534.

110 BOP, B3.6, n 82, C, s. 26-27; ABBAW, NL Kirch, Nr. 5, s. 14. 
Syna Christfrieda wysłał Kirch w maju 1708 r. do szkoły łacińskiej w Halle ${ }^{111}$. 4 kwietnia 1709 r. wydał za mąż najstarszą, dwudziestosześcioletnią córkę Theodorę. Jej wybrankiem został Johann Georg Gading, kantor w berlińskim Kościele Garnizonowym ${ }^{112} .18$ stycznia 1710 r. przyszła na świat pierwsza córka tej pary ${ }^{113}$. Z dziećmi z pierwszego małżeństwa Kirch od dawna nie miał już kontaktu. W mowie pogrzebowej Reinbeck, obrazując dzieje dwóch jego pozostałych synów (Gottlieba i Heilmanna), zaznaczył, że obaj „poszli na obczyznę" i że sam astronom od wielu lat nie otrzymał od nich żadnej wiadomości ${ }^{114}$.

W 1710 r. ukazał pierwszy tom „Miscellanea Berolinensia”, wydawnictwa Królewskiego Pruskiego Towarzystwa Nauk. Kirch, który zaraz po Leibnizu był autorem największej liczby artykułów, otrzymał swój egzemplarz 17 czerwca ${ }^{115}$. Artykuły astronoma prezentowały, z jednej strony, jego dawne osiągnięcia: mikrometr śrubowy i wyniki obserwacji z 7/17 stycznia 1679 r., na którą został przygotowany, meldunek o odkrytej w 1680 r. komecie oraz badania gwiazdy zmiennej $\chi$ Cygni ${ }^{116}$. Z drugiej strony do druku trafiły jego obserwacje z okresu berlińskiego: komety z 1702 r., koniunkcji Saturna i Jowisza z 1702 r., przejścia Merkurego na tle tarczy Słońca z 1707 r. i zorzy polarnej z 1707 r. ${ }^{117}$

Stan zdrowia Gottfrieda Kircha zaczął się pogarszać 12 lipca 1710 r. Astronom zmarł 25 lipca 1710 r. Jego pogrzeb odbył się 29 lipca. 3 sierpnia, w dziesiątą rocznicę przyjazdu rodziny Kirchów do Berlina, odprawiona została msza upamiętniająca uczonego ${ }^{118}$. Nie doczekał Kirch ceremonii uroczystego otwarcia Królewskiego Pruskiego Towarzystwa Nauk, podczas której 19 stycznia 1711 r. przekazano oficjalnie instytucji klucze do obserwatorium i pieczęć 119 .

Gottfried Kirch należał do grona uznanych astronomów schyłku XVII i początku XVIII w. Znany był dzięki swoim odkryciom, wydawanym efemerydom oraz pisanym kalendarzom. Początki jego działalności, aczkolwiek zarysowane mgliście, przypadały na pobyty uczonego w Langgrün i Lobenstein. Swoje zainteresowania rozwijał dalej w Lipsku. Tam też jego kariera osiągnęła szczytowy punkt. Z okresu pobytu w tym mieście i paromiesięcznej wizyty w Coburgu pochodzą najważniejsze jego dokonania. Nastąpił po nim przejściowy okres spędzony w Gubinie, który skończył się wraz z otrzymaniem powołania do Berlina. Działalność Kircha jako pierwszego astronoma Królewskiego Pruskiego Towarzystwa Nauk, która przypadła na ostatnią dekadę jego życia, stanowiła prestiżowe zwieńczenie jego kariery.

111 BOP, B3.6, n 82, B, s. 91; Archiv der Franckeschen Stiftungen, S L 1 Schülerverzeichnis der Lateinischen Schule der Franckeschen Stiftungen Halle, 1699-1712, s. 211.

112 BOP, B3.6, n 82, C, s. 64.

113 DMB, Sign. I B 1 M.M. Kirch, Gewitter=Aufzeichnung im Jahr 1710, 18. Jan.

114 J.G. Reinbeck, op. cit., s. 25.

115 BOP, B3.6, n 82, D, s. 17. Jul.

116 G. Kirch, De simplicissima quadam specie Micrometri, „Miscellanea Berolinensia” t. 1, 1710, s. 202-205; idem, Occultatio stellae fixae in cornu Australi Tauri o Bayeri, â Saturno facta observata Lipsiae An. 1679. die 7. (17) Januarii, „Miscellanea Berolinensia” t. 1, 1710, s. 205-208; idem, De varia apparentia stellae in collo Cygni, „Miscellanea Berolinensia” t. 1, 1710, s. 208-212; idem, De Cometa matutino Anni 1680, „Miscellanea Berolinensia" t. 1, 1710, s. 215-216.

117 Idem, Brevis Descriptio clari cujusdam Luminis, Anno 1707. die 6. Martii, Dominica quinquagesimae, Berolini vespeperi, versus septemtrionem visi, „Miscellanea Berolinensia” t. 1, 1710, s. 135-137; idem, De cometa Anno 1702. Berolini observato, s. 212-215; idem, Observatio Conjunctionis Magnae Saturni \& Jovis Anno 1702, „Miscellanea Berolinensia” t. 1, 1710, s. 216-217; idem, De Mercurio in Sole, Anno 1707, „Miscellanea Berolinensia" t.1, 1710, s. 218-219.

118 Ch. Ranßleben, Jesu Herrlichkeit/ Die Er nach seiner Menschheit erhalten in der Zeit [...], Cölln an der Spree [b.r.], k. Ar.

119 A. Harnack, op. cit., s. 209-210. 
Bibliografia

\section{Źródła archiwalne}

Archiv der Berlin-Brandenburgischen Akademie der Wissenschaften:

- Nachlass Kirch, Nr. 1-5;

- Preußische Akademie der Wissenschaften (1700-1811), I-II-1, I-IV-6, I-XVI:66-75.

Archiv der Franckeschen Stiftungen zu Halle, Schularchiv L 1.

Archiwum Państwowe w Zielonej Górze, Akta metrykalne Gubin/Guben, sygn. 6, 7.

Bibliothèque de l'Observatoire de Paris:

- G. Kirch, Journal autographe de ses observations, 1677-1710, B 3.1-6;

- Observations de M. Kirch le père, traduites de I'allemand, 1684-1707, B 2.15-16.

Brandenburgisches Landeshauptarchiv Potsdam, Stadt Guben - Akten (1430-1954), Sig. 6.

Deutsche Meteorologische Bibliothek, [Beobachtungen Berlin, z. TI. Gewitterbeobachtungen], Sign. I B 1.

\section{Źródła drukowane}

Christen-, Juden- und Türken- Kalender für das Jahr 1667 verfaßt von Gottfried Kirch, red. K.-D. Herbst, Jena 2009 (Acta Calendariographica - Kalenderreihen, t. 1, z. 1).

Die iüngere Matrikel der Universität Leipzig 1559-1809. Als Personen- und Ortsregister bearbeitet und durch Nachträge aus den Promotionslisten ergänzt, t. 2, Die Immatrikulationen vom Wintersemester 1634 bis zum Sommersemester 1709, red. G. Erler, Leipzig 1909.

Die Korrespondenz des Astronomen und Kalendermachers Gottfried Kirch (1639-1710), t. 1-3, red. K.-D. Herbst, Jena 2006.

Döring D., Der Briefwechsel zwischen Gottfried Kirch und Adam A. Kochanski 16801694. Ein Beitrag zur Astronomiegeschichte in Leipzig und zu den deutsch-polnischen Wissenschaftsbeziehungen, Berlin 1997 (Abhandlungen der Sächsischen Akademie der Wissenschaften zu Leipzig, Philologisch-Historische Klasse, t. 74, z. 5).

Harnack A., Geschichte der Königlich Preussischen Akademie der Wissenschaften zu Berlin, t. 2, Urkunden und Actenstücke zur Geschichte der Königlich Preussischen Akademie der Wissenschaften, Berlin 1900.

Herbst K.-D., Astronomie um 1700. Kommentierte Edition des Briefes von Gottfried Kirch an Olaus Römer vom 25. Oktober 1703, Thun-Frankfurt am Main 1999 (Acta Historica Astronomiae, t. 4).

Kirch G., Brevis Descriptio clari cujusdam Luminis, Anno 1707. die 6. Martii, Dominica quinquagesimae, Berolini vespeperi, versus septemtrionem visi, „Miscellanea Berolinensia” t. 1, 1710, s. 135-137.

Kirch G., Christen = Jüden $=$ und Türcken $=$ Kalender/ Auf das Jahr Jesu Christi 1696, Nürnberg [b.r.]. 
Kirch G., De cometa Anno 1702. Berolini observato, „Miscellanea Berolinensia” t. 1, 1710, s. 212-215.

Kirch G., De Cometa matutino Anni 1680, „Miscellanea Berolinensia” t. 1, 1710, s. 215216.

Kirch G., De Mercurio in Sole, Anno 1707, „Miscellanea Berolinensia” t. 1, 1710, s. 218-219.

Kirch G., De simplicissima quadam specie Micrometri, "Miscellanea Berolinensia” t. 1, 1710 , s. 202-205.

Kirch G., De varia apparentia stellae in collo Cygni, „Miscellanea Berolinensia” t. 1, 1710, s. 208-212.

Kirch G., Godofredi Kirchii Observationes Cometae Novi, habitae Berolini a. d. 21 April. 1702, "Acta Eruditorum” 1702, nr 6 s. 256-258.

Kirch G., Neue Himmels=Zeitung [...], Nürnberg 1681.

Kirch G., Observatio Conjunctionis Magnae Saturni \& Jovis Anno 1702, „Miscellanea Berolinensia" t. 1, 1710, s. 216-217.

Kirch G., Occultatio stellae fixae in cornu Australi Tauri Bayeri, â Saturno facta observata Lipsiae An. 1679. die 7. (17) Januarii, „Miscellanea Berolinensia” t. 1, 1710, s. 205-208.

Kirch G., Stella nebulosa propè pedem borealem Ganymedis observata, Lipsiae, die 1. Sept. Anno 1681, [w:] idem, Annus II. Ephemeridum Motuum Coelestium Ad Annum Aerae Christianae M. DC. LXXXII [...], Lipsiae [b.r.].

Kirch G., Stellae In Cygno Fixae, Alternis Temporibus visae \& invisae, vicissitudines Lipsiae observatae a Godofredo Kirchio, "Acta Eruditorum” 1687, nr 11, s. 647-648.

Leibniz und seine Akademie. Ausgewählte Quellen zur Geschichte der Berliner Sozietät der Wissenschaften 1697-1716, red. H.-S. Brather, Berlin 1993.

Ranßleben Ch., Jesu Herrlichkeit/ Die Er nach seiner Menschheit erhalten in der Zeit [...], Cölln an der Spree [b.r.].

Reinbeck J.G., Die Stern=Kunst/ Nach ihrem Mißbrauch und rechten Gebrauch [...], Cölln an der Spree [b.r.].

Vignoles des A., Eloge de M. Kirch le Fils, Astronome de Berlin, "Journal littéraire d'Allemagne, de Suisse et du Nort" t. 1, 1741, s. 300-351.

Vignoles des A., Eloge de Madame Kirch, à l'occasion de laquelle on parle de quelques autres Femmes \& d'un Paisan Astronomes, „Bibliotheque germanique ou Histoire litteraire de l'Allemagne, de la Suisse, et des Pays du Nord" t. 3, 1721 [dr. 1722], s. $155-183$.

\section{Literatura przedmiotu}

Amburger E., Die Mitglieder der Deutschen Akademie der Wissenschaften zu Berlin 17001950, Berlin 1950.

Brather H.-S., Leibniz und das Konzil der Berliner Sozietät der Wissenschaften, "Studia Leibnitiana. Zeitschrift für Geschichte der Philosophie und der Wissenschaften" 1990, z. spec. 16, s. 218-230.

Dobrzycki J., Włodarczyk J., Historia naturalna gwiazdozbiorów, Warszawa 2002.

Döring D., Acta Eruditorum, [w:] Zur Alltagsgeschichte der Philosophie in Leipzig, red. K.-D. Eichler, U.J. Schneider, Leipzig 2004 (Leipziger Schriften zur Philosophie, t. 18), s. $32-33$. 
Hamel J., Erhard Weigel und die Kalenderreform des Jahres 1700, [w:] Erhard Weigel - 1625 bis 1699. Barocker Erzvater der deutschen Frühaufklärung. Beiträge des Kolloquiums anläßlich seines 300. Todestages am 20. März 1999 in Jena, red. R.E. Schielicke, K.-D. Herbst, S. Kratochwil, Thun - Frankfurt am Main 1999 (Acta Historica Astronomiae, t. 7), s. 135-156.

Hamel J., Geschichte der Astronomie. Von den Anfängen bis zur Gegenwart, Basel Boston - Berlin 1998.

Hamel J., Wissenschaftsförderung und Wissenschaftsalltag in Berlin 1700-1720 - dargestellt anhand des Nachlasses des ersten Berliner Akademieastronomen Gottfried Kirch und seiner Familie, "Sitzungsberichte der Leibniz-Sozietät” t. 55, 2002, z. 4, s. 61-101.

Herbst K.-D., Der Astronom Gottfried Kirch (1639-1710) im Vogtland, „Jahrbuch des Museums Reichenfels-Hohenleuben" 2001, z. 46, s. 95-104.

Herbst K.-D., Die Astronomie in der Mitte des 17. Jahrhunderts und ihre Förderung durch Ernst den Frommen in Gotha und Albrecht in Coburg, [w:] Ernst der Fromme (1601-1675). Staatsmann und Reformer. Wissenschaftliche Beiträge und Katalog zur Ausstellung, red. R. Jacobsen, H.-J. Ruge, Bucha bei Jena 2002 (Veröffentlichungen der Forschungsbibliothek Gotha, 39), s. 261-276.

Herbst K.-D., Die astronomischen Instrumente von Gottfried Kirch, [w:] Der Meister und die Fernrohre. Das Wechselspiel zwischen Astronomie und Optik in der Geschichte. Festschrift zum 85. Geburtstag von Rolf Riekher, red. J. Hamel, I. Keil, Frankfurt am Main 2007 (Acta Historica Astronomiae, t. 33), s. 203-228.

Herbst K.-D., Die Kalender von Gottfried Kirch, [w:] Beiträge zur Astronomiegeschichte, t. 7, red. W.R. Dick, J. Hamel, Frankfurt am Main 2004 (Acta Historica Astronomiae, t. 23), s. 115-159.

Herbst K.-D., Neue Erkenntnisse zur Biographie von Gottfried Kirch, [w:] 300 Jahre Astronomie in Berlin und Potsdam. Eine Sammlung von Aufsätzen aus Anlaß des Gründungsjubiläums der Berliner Sternwarte, red. W.R. Dick, K. Fritze, Thun - Frankfurt am Main 2000 (Acta Historica Astronomiae, t. 8), s. 71-85.

Herbst K.-D., Wer half dem Astronomen Gottfried Kirch?, [w:] Unsichtbare Hände. Zur Rolle von Laborassistenten, Mechanikern, Zeichnern u. a. Amanuenses in der physikalischen Forschungs- und Entwicklungsarbeit, red. K. Hentschel, Diepholz - Stuttgart - Berlin 2008, s. 51-68.

Herbst K.-D., Zum 300. Todestag des Astronomen und Kalendermachers Gottfried Kirch, [w:] Gottfried Kirch (1639-1710) und die Berliner Astronomie im 18. Jahrhundert. Beiträge des Kolloquiums am 6. März 2010 in Berlin-Treptow, red. J. Hamel, Frankfurt am Main 2010 (Acta Historica Astronomiae, t. 41), s. 22-33.

Jones K.G., Messier's Nebulae and Star Clusters, Cambridge 1991.

Kanas N., Star Maps. History, Artistry, and Cartography, Berlin - Heidelberg - New York 2007.

Kronk G.W., Cometography. A Catalog of Comets, t. 1, Ancient-1799, Cambridge 1999.

Maeyama Y., Tables and Ephemerides, [w:] Encyclopedia of the Scientific Revolution. From Copernicus to Newton, red. W. Applebaum, New York 2005, s. 48-50.

Warner D.J., The Sky Explored. Celestial Cartography 1500-1800, New York 1979.

Wattenberg D., Dynastien und Astrognosie, „Die Sterne” r. 38, 1962, z. 11/12, s. 226-235. 
Włodarczyk J., Jasiński M., Jan III Sobieski i uranografia polityczna XVII stulecia, [w:] Primus Inter Pares. Pierwszy wśród równych, czyli opowieść o królu Janie III, red. D. Walawender-Musz, Warszawa 2013, s. 140-145.

Strony internetowe

Gottfried Kirch (1639-1710) - Astronom und Kalendermacher, gottfried-kirch-edition.de [dostęp 21.11.2020].

Herbst K.-D., Biobibliographisches Handbuch der Kalendermacher von 1550 bis 1750, www. presseforschung.uni-bremen.de/dokuwiki/doku.php?id=Startseite [dostęp 11.01.2021].

dr Justyna Rogińska, doktor nauk humanistycznych w dyscyplinie naukowej historia, adiunkt w Pracowni Historii Nauk Ścisłych Instytutu Historii Nauki im. L. i A. Birkenmajerów PAN. Zainteresowania naukowe: historia wczesnonowożytnej astronomii i meteorologii, kalendariografia niemiecka.

e-mail: jroginska@ihnpan.pl

Data zgłoszenia artykułu: 14 lutego 2021

Data przyjęcia do druku: 14 maja 2021 